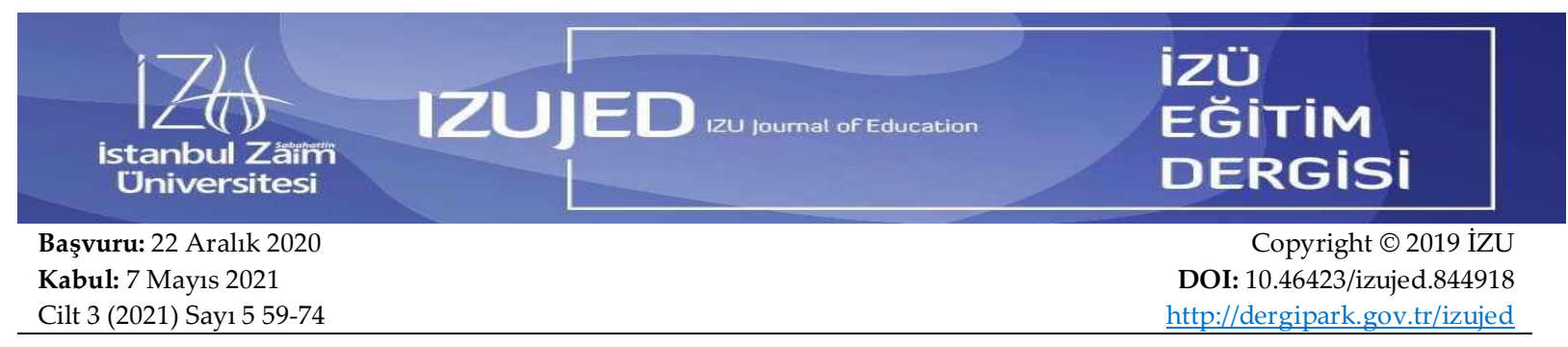

\title{
İkili Eğitim Yapan Okulların Yöneticilerinin Tam Gün (Normal) Eğitime Geçiş Hakkında Görüsşleri
}

\author{
Mehmet ÖZDOĞRUa
}

Öz

Bu araştırmanın amacı, Milli Eğitim Bakanlığına bağlı ilkokul ve ortaokulların tam gün (normal) eğitime geçişi hakkında ikili eğitim yapan okul yöneticilerinin görüşlerini ortaya koymaktır. Çalışma nitel araştırma yöntemlerinden durum çalışması desenine göre yapılmıştır. Araştırmada, çalışma grubunun belirlenmesinde amaçlı örnekleme yöntemlerinden, maksimum çeşitlilik ve ölçüte dayalı örnekleme tekniği kullanılmıştır. Araştırmanın çalışma grubu ikili eğitim yapan ilkokul ve ortaokullarda görev yapan yirmi okul yöneticisinden oluşmaktadır. Araştırmada veri toplama aracı olarak yarı yapılandırılmış görüşme formu kullanılmıştır. Verilerin çözümlenmesinde içerik analizi tekniği kullanılmıştır. Araştırma bulgularına göre, ikili eğitimden tam gün eğitime geçişte karşılaşılabilecek sorunlar; öğrencilerin beslenme sorunu, fiziki mekân yetersizliği, sınıfların kalabalıklaşması, kayıt alanı dışından gelen öğrenciler, öğretmenlerin norm fazlası olma durumu, yeni okul binası yapımıyla ilgili sorunlar ve deprem dayanıklılık testleri sonucu mevcut okul binalarına boşaltma kararı çıması nedeninden kaynaklanan durumlar olarak tanımlanabilir. Okul yöneticileri tarafından getirilen çözüm önerileri; okullara yemekhane açılması ve öğlen arası evine gidemeyen öğrencilere yemek verilmesinin sağlanması, kayıt alanı dışından öğrenci alımının önüne geçilmesi, öğrenci yoğunluğu göz önünde bulundurularak yeni okul binalarının ve dersliklerin hizla yapılması, okulların fiziki alt yapısı tamamlandıktan sonra tam güne kademeli olarak geçiş yapılması, merkez ve kenar mahalle okulları arasındaki eğitim yönünden farklılıkların giderilmesi, deprem dayanıklılık testini geçemeyen binaların yapımına öncelik verilmesi, norm fazlası öğretmenlerin başka okullarda değerlendirilmesi şeklindedir.

Anahtar Kelimeler: İkili Eğitim, Tam Gün Eğitim, Ilkokul, Ortaokul, Ikili Öğretim, Tam Gün Öğretim

\section{Views of the Principals of Dual Education Schools on Transition to Full-Time (Normal) Education}

\begin{abstract}
The aim of this research is to reveal the views of school administrators who conduct dual education about the transition of primary schools affiliated to MEB to full-time (normal) education. The study was conducted according to the case study design, one of qualitative research methods. In the study, criterion-based sampling technique, one of the purposeful sampling methods, was used to determine the study group. The study group of the research consists of twenty school principals working in primary schools with dual education. Semi-structured interview form was used as data collection tool in the study. Content analysis technique was used in analyzing the data. According to the findings of the research, the problems that can be encountered in transition from dual education to full-time education; nutritional problems of students, lack of physical space, crowding of classrooms, students coming from outside the registration area, excessive teachers' status, problems related to the
\end{abstract}

a Sorumlu Yazar: Dr., Milli Eğitim Bakanlığı, Eskişehir, Turkey, mehmetozdogru26@gmail.com ORCID: https://orcid.org/0000-0002-3853-8389

Atıf: Özdoğru, M. (2021). İkili eğitim yapan okulların yöneticilerinin tam gün (normal) eğitime geçiş hakkında görüşleri. İZü Eğitim Dergisi, 3 (5) 59-74. DOI: 10.46423/izujed.844918 
construction of new school buildings and the decision to evacuate existing school buildings as a result of earthquake resistance tests. Solution suggestions brought by school principals; opening a cafeteria in schools and providing meals to students who cannot go to their homes during lunch break, preventing student admission from outside the registration area, making new school buildings and classrooms rapidly considering the student density, making a gradual transition to full day after completing the physical infrastructure of the schools, Eliminating the differences in terms of education between neighborhood schools, giving priority to the construction of buildings that do not pass the earthquake resistance test, and evaluating teachers who are over the norm in other schools.

Keywords: Dual Education, Full-Time Schooling, Primary School, Secondary School, Dual, Full-Time Training

\section{Extended Abstract}

\section{Introduction}

Countries have to fulfill some conditions in order to achieve the goals they have set regarding education and to continue the education-training process successfully. One of the priorities of these conditions is that the physical infrastructure of the schools is sufficient to provide a modern and ideal education service (Pınar \& Sarıbaş, 2009).

The schools where primary education (Ünal, 2001), which is seen as the basis and starting point of all developments, is different due to the number of classrooms, transportation facilities, the number of students, the number of teachers, the physical condition of the school building, the socioeconomic status of the location and geographical factors. This difference also affected the duration of education in schools.

When studies on teaching time in schools are examined, it is seen that full-time education offers a more effective teaching time than dual education (Herry, Maltais \& Thompson, 2007; Gullo, 2000; Lee, Burkam, Ready, Honigman, \& Meisels, 2006)

The Ministry of National Education has announced that normal education will begin in all schools until 2019. In the statements made by the Ministry, it was stated that the dual education will be abolished and full-time education will be started, and it has also stated that approximately 77 thousand classrooms are needed (TRT, 2017).

Considering the elapsed time period, it is seen that the ministry could not make enough progress in the transition from dual education to full-time education. In order for the transition process to take place quickly and successfully, it is necessary to determine the problem areas that may be encountered in advance and to act within a planning. For this reason, we can say that the opinions of the school administrators who will carry out the transition from dual education to full-time education in the field are important. From this point of view, it can be said that this research, in which the problems that can be encountered in transition from dual education to full-time (normal) education and suggestions for the solution of these problems, will contribute to the field.

\section{Method}

This research is a qualitative study aimed at determining the problems that may be encountered in transition from dual education to full-time (normal) education and the opinions of the administrators of the dual education schools to solve these problems. In the study in which the case study pattern, one of the qualitative research designs, was used, it was 
aimed to examine the problems that may be encountered in transition to (normal) education and the suggestions for the solution of these problems.

The study group was formed in accordance with the maximum diversity and criterion sampling among the purposeful sampling methods of the study. Regarding the problem of the research, 20 school principals working in primary and secondary schools.

In the study, a semi-structured interview form was used to examine the problems. Content analysis technique was used to analyze the data obtained in the study.

\section{Findings and Discussion}

School principals' views on the problems they may encounter in transition from dual education to full-time education; nutritional problem (lunch, etc.) $(\mathrm{n}=16)$, lack of physical space (number of classrooms, etc.) $(n=13)$, crowded classes $(n=11)$, students coming from outside the registration area $(n=8)$, teachers' norm $(n=7)$, problems with the construction of new school buildings $(n=5)$, and insufficiency of educational materials $(n=1)$. According to this, it was stated that there are more than one problem area by school administrators who do dual education during the transition to full-time education. According to Table 3, solution suggestions for the problems that school administrators may encounter in transition from dual education to full-time education; After completing the preparations, moving to the full day gradually ( $n=19)$, meeting the need for lunch $(n=18)$, accelerating the construction process of the school buildings $(n=15)$, eliminating the differences between schools $(n=14)$, student registration outside the registration area prevention $(n=11)$ and employing teachers who will have more than the norm $(n=10)$.

Solution suggestions for the problems that school principals may encounter in transition from dual education to full-time education; After completing the preparations, moving to the full day gradually $(n=19)$, meeting the need for lunch $(n=18)$, accelerating the construction process of school buildings $(\mathrm{n}=15)$, eliminating the differences between schools $(\mathrm{n}=14)$, enrollment from outside the registration area prevention $(n=11)$ and employing teachers who will have more than the norm $(n=10)$.

In the study, the opinions of the administrators of the dual education schools regarding the problems that may be encountered in transition from dual education to full-time (normal) education and suggestions for the solution of these problems were presented. As a result of the research, nutritional problems (lunch, etc.), lack of physical space (number of classes, etc.), crowding of classrooms, students coming from outside the registration area, excessive teachers' status, problems related to the construction of a new school building, and insufficient education It was stated as problems that may be encountered in transition to (normal) education.

The solution suggestions by the participants of the research regarding the problems that may be encountered in transition from dual education to full-time education; After the preparations are completed, the full day is gradually started, the need for lunch, the acceleration of the construction process of the school buildings, the elimination of the differences between the schools, the prevention of student registration from outside the registration area and the employment of teachers who will be more than the norm.

Based on the research findings, the following suggestions can be made: 
1. Before deciding on the schools that will switch to full-time education, the existing physical infrastructure of the schools should be reviewed.

2. During the transition from dual education to full-time education, information on the number of students, enrollment areas, and number of teachers should be collected in a database, and the decisions to be made should be based on data.

\section{Giriș}

Eğitim, bireylere çevrelerinde oluşan değişimlere uyum sağlayabilmeleri için yeni davranışlar kazandırmakla yükümlüdür. Eğitim sisteminin bu yükümlülügünü yerine getirebilmesi, hızla değişen bilgi ve teknolojiye ayak uyduracak bir niteliğe erişmesi ile mümkündür. İnsanı, hem çevredeki değişimlere uyum sağlayacak hem de değişim yaratacak yeterliliğe ulaştırmak eğitimin görevi olunca, eğitim sisteminin sürekli bir değişme ve yenileşme içinde olması gerekmektedir (Ereş, 2005).

Ülkelerin kalkınmayla ilgili belirlediği hedeflerine ulaşmada öncelikle üzerinde durduğu etkinlik alanlarından biri de eğitimdir. Dünyada hızla meydana gelen gelişmeler eğitim sistemlerini de etkilemektedir. Ülkeler bu gelişmelere entegre olabilmek için vatandaşlarına sunduğu eğitim hizmetinin niteliğini geliştirmek zorundadır. Eğitim sistemlerindeki değişim ve gelişimin doğru ve hızlı olabilmesi atılacak adımların önceden titizlikle planlanmasıyla yakından ilgilidir. Aksi takdirde eğitim alanında yapılacak reformların aynı zamanda yeni sorunlara yol açması kaçınılmaz olacaktır. Ülkelerin eğitimle ilgili belirledikleri hedeflere ulaşması ve eğitim-öğretim sürecini başarıyla sürdürebilmesi için bazı şartları yerine getirmesi gerekmektedir. Bu şartlardan öncelikli olanlardan birisi de okulların fiziki alt yapısının çağdaş ve ideal bir eğitim hizmeti sunmak için yeterli düzeyde olmasıdır (Pınar \& Sarıbaş, 2009).

Bütün kalkınmaların temeli ve hareket noktası olarak görülen ilköğretimin (Ünal, 2001) verildiği okullar, derslik sayısı, ulaşım imkânı, öğrenci sayıları, öğretmen sayıları, okul binasının fiziki durumu, bulunduğu yerin sosyoekonomik durumu ve coğrafi etmenlerden dolayı farklılık arz etmektedir. Bu farklılık, okullardaki eğitim sürelerini de etkilemiştir. Ülkemizde okulların durumlarına göre tam gün ve ikili eğitim sistemi uygulanmaktadır (Kocaoluk, 1991). Okullarda uygulanmakta olan tam gün ve ikili eğitim uygulamaları öğretim zamanı açısından değerlendirildiğinde birbirinden çok farklı özellikte uygulamalar olduğu görülmektir.

İkili eğitim “okul öncesi eğitim ve ilköğretim kurumlarında ayrı gruplarla sabah ve öğleden sonra yapılan eğitim" olarak tanımlanmakla birlikte genelde sabahçı-öğleci ya da yarım gün eğitim uygulaması olarak bilinmektedir. Normal eğitim ise "ilköğretim kurumlarında sabah ve öğleden sonrayı kapsayacak şekilde yapılan" ve tam gün olarak da adlandırılan eğitimdir (MEB İKY, 2014).

Okullardaki öğretim zamanıyla ilgili yapılan çalışmalar incelendiğinde tam gün eğitimin ikili eğitime göre daha etkili bir öğretim zamanı sunduğu görülmektedir (Gullo, 2000; Herry, Maltais \& Thompson, 2007; Lee, Burkam, Ready, Honigman, \& Meisels, 2006).

İkili eğitim yapılan okulları incelediğimizde ikili eğitimin bir tercih değil zorunluluktan uygulandığı anlaşılmaktadır. Okullarda ikili eğitim yapılmasının başlıca nedenlerine baktığımızda ise şu noktalar karşımıza çıkmaktadır:

a. Kırsaldan kent merkezine yapılan göçün oluşturduğu yoğun nüfus (Camuzcu, 2007). 
b. "4+4+4" eğitim düzenlenmesi sonucu ilkokul ve ortaokulların ayrı binalarda ayrı kurumlar olarak eğitim görmesinin benimsenmesi (Akbaşlı \& Üredi, 2014).

c. Kayıt alanlarına göre okula kayıt yöntemin çeşitli yollarla (adres taşıma vb.) delinmesi (Yücel, Boyacı, Demirhan \& Karataş, 2013).

d. Nüfus artışına paralel yeterli derslik ve okul binası yapılamaması (ERG, 2014)

Aslında Milli Eğitim Bakanlığı'da yukarıda açıklanan sorunların farkındadır. Bakanlık "MEB 2015- 2019 Stratejik Planı"nda derslik başına düşen öğrenci sayısındaki bölgesel farklılıkları ve ikili eğitim uygulamaların eğitimde zayıf yanlarından biri olarak belirlemiştir (MEB, 2015).

Türkiye'de normal koşullarda bir okulda tam gün boyunca eğitim-öğretim faaliyetleri gerçekleştirilmekte iken bazı okulların fiziksel olanaklarının, derslik azlığı ya da öğrenci yoğunluğu gibi nedenlerden dolayı aynı binada iki farklı öğretim yapılarak gereksinimler karşılanmaya çalışılmaktadır (Aktay, Işık \& Gençsoy, 2019).

Eğitim yöneticilerinin Türk Milli Eğitim Sisteminin sorunlarından en önemlisi olarak sıraladığı diğer sorunların başında ikili öğretim uygulaması gelmektedir (Karakütük \& Özdoğan, 2019). Normal öğretime göre ikili öğretim faaliyetlerine devam eden okullarda öğrencilerin yaşadıkları birçok problem mevcuttur (Onarıcıoğlu, 2018). İkili eğitimin uygulamasının eğitim sistemimize yansıyan başlıca dezavantajları; teneffüslerin kısalması ile öğrenci ve öğretmenlerin yeterince dinlenememesi (Camuzcu, 2007), sabah çok erken okula gelinmesi ve akşam geç vakitte okuldan ayrılmadan kaynaklı öğrencilerde uyku düzensizliğine sebep olması (Yurdabakan \& Tektaş (2013), okulda ders dışında sosyal aktivite yapmaya zaman kalmaması (Camuzcu, 2007), idari personelin çalışma süresinin artması ve zorlaşması (Özan \& Öztürk, 2018) olarak gösterebilir.

UNESCO ve OECD gibi uluslararası kuruluşlar okul süresinin eğitim ve öğretim kalitesinin arttırılmasındaki en önemli faktörlerden biri olduğunu belirtmektedirler. Bu durum zorunlu okul süresine, yıllık okul günü sayısına ve öğrencilerin bir günün kaç saatini okulda geçirdiğine dikkat edilmesine neden olmaktadır. Tam gün okullar öğrencilerin sağlıklı, tarafsız ve kaliteli bir çevrede yararlı bir eğitime ulaşma haklarını kolaylaştıracak ve uygulanmasını sağlayacak yeni şartları teşvik etmektedir. Ayrıca tam gün eğitim yapan okullarda öğretmenler eğitimi, okumayı, yazmayı, sözlü ifadeyi, bilimsel ve matematiksel eleştirel düşünmeyi ve analizi vb. pekiştirmek için daha fazla zamana sahip olurlar (OECD, 2007).

Okullarda öğretim zamanının tam gün olarak uygulanmasının eğitime olumlu yönde yansımaları olmaktadır. Bunlar; öğrencilere derslerin yanında okulda sosyal aktivite yapmaya zaman sunması, öğrencilerin çok erken saatlerde kalkmasını ve akşam geç saatlerde okullardan ayrılmasını gerektirmemesi, öğrenci ve öğretmene okul dişında yeterli dinlenme süresi sunması, teneffüs sürelerinin öğrenci ihtiyaçlarını karşılayacak seviyede olması, öğrencilerin sabah kahvaltısı yapması ve öğlen yemeği için gerekli süreyi sunması olarak sıralanabilir. Görüldüğü gibi okullarda etkili bir öğretim zamanı geçirilmesi için tam gün eğitimin gerekli olduğunu söyleyebiliriz. Ancak okulların ikili eğitimden tam güne geçiş süreci iyi planlanarak yönetilmeli, oldu bittiye getirilerek sonrasında daha karmaşık problemlere yol açılmamalıdır. Bu nedenle geçiş sürecinde karşılaşılabilecek sorunları önceden tespit etmek önem arz etmektedir. 
Milli Eğitim Bakanlığı 2019 yılına kadar tüm okullarda normal eğitime geçileceğini açıklamıştır. Bakanlık yaptığı açıklamalarda ikili eğitimin kaldırılarak tam gün eğitime geçileceği, bunun gerçekleşmesi için de yaklaşık 77 bin dersliğe ihtiyaç duyulduğunu belirtmiştir (TRT, 2017). Ancak 2019 yılı sonu itibariyle ikili eğitime devam eden temel eğitim kurumlarındaki öğrenci oranı \%33,83 tür (MEB, 2020). Geçen zaman dilimi dikkate alındığında ikili eğitimden tam gün eğitime geçişte bakanlığın yeterince mesafe kat edemediği görülmektedir. Geçiş sürecinin hızlı ve başarılı bir şekilde gerçekleşmesi için karşılaşılabilecek sorun alanlarının önceden tespit edilerek bir planlama dâhilinde hareket edilmesi gerekmektedir. $\mathrm{Bu}$ nedenle ikili eğitimden tam gün eğitime geçiş sürecini sahada gerçekleştirecek olan ikili eğitim yapan okul yöneticilerinin süreçle ilgili görüşlerinin önem arz ettiği söylenebilir. Bu açıdan bakıldığında ikili eğitimden tam gün (normal) eğitime geçişte karşılaşılabilecek sorunların ve bu sorunların çözümüne yönelik önerilerin tespit edildiği bu araştırmanın alana katkı sağlayacağı düşünülmektedir.

\section{Amaç}

$\mathrm{Bu}$ araştırmanın genel amacı, ikili eğitimden tam gün (normal) eğitime geçişte karşılaşılabilecek sorunları ve bu sorunların çözümüne yönelik önerileri ikili eğitim yapan okulların yöneticilerinin görüşleri doğrultusunda incelemektir. Bu doğrultuda ikili eğitim yapan okul yöneticilerinin görüşlerine başvurularak tam gün (normal) eğitime geçişte karşılaşılabilecek sorunlar ortaya konulmuş ve bu sorunlara çözüm önerileri sunulmuştur. Araştırma kapsamında aşağıdaki sorulara cevap aranmıştır:

Okul yöneticilerinin görüşlerine göre ikili eğitimden tam gün eğitime geçişte karşılaşılabilecek sorunlar nelerdir?

Okul yöneticilerinin görüşlerine göre ikili eğitimden tam gün eğitime geçişte karşılaşabilecek sorunlar nasıl çözülebilir?

\section{Yöntem}

\section{Araştırmanın Deseni}

$\mathrm{Bu}$ araştırma ikili eğitimden tam gün (normal) eğitime geçişte karşılaşılabilecek sorunları ve bu sorunların çözümüne yönelik ikili eğitim yapan okulların yöneticilerinin görüşlerini belirlemeye yönelik yapılan nitel bir çalışmadır. Nitel araştırma desenlerinden durum çalışması deseninin kullanıldığı araştırmada ikili eğitim yapan okul yöneticilerinin (normal) eğitime geçişte karşılaşılabilecek sorunlara ilişkin ve bu sorunların çözümüne yönelik önerilerin derinlemesine incelenmesi amaçlanmıştır. Durum çalışmasında amaç, belirli bir durumla ilgili sonuçlar ortaya çıkarmak ve belirlenen konu ile ilgili derinlemesine araştırma yapmaktır (Yıldırım \& Şimşek, 2016). Bu araştırmada incelenen durum MEB'in 2015-2019 Stratejik Planı'nda 2019 yılı sonu itibariyle ülke genelinde ikili eğitim uygulamasının sonlandırılarak tam gün (normal) eğitime geçeceğini belirtmesi ve bu durumun gerçekleşmesi için karşılaşılabilecek sorunların önceden tespit edilmesi ve bunlara yönelik çözüm önerileri getirilmesidir.

\section{Katılımcilar}

Araştırmada amaçlı örnekleme yöntemlerinden maksimum çeşitlilik ve ölçüt örneklemesine uygun olarak çalışma grubu oluşturulmuştur. Maksimum çeşitlilik örneklemede evrende 
araştırılacak problemle ilgili kendi içinde benzeşik farklı durumların belirlenerek, çalışmanın bu durum çerçevesinde yapılması önemlidir (Büyüköztürk, Çakmak, Akgün, Karadeniz \& Demirel, 2014). Maksimum çeşitlilik örneklemesindeki amaç, küçük bir örneklem oluşturmak ve bu örneklemde çalışılan probleme taraf olabilecek bireylerin çeşitliliğini maksimum derecede yansıtmaktır (Yıldırım \& Şimşek, 2016). Bu nedenle araştırmanın problemiyle ilgili Eskişehir ili Odunpazarı ve Tepebaşı ilçelerindeki ilkokul ve ortaokullarda çalışan 20 okul yöneticisi çalışma grubunu oluşturmuştur.

Okul yöneticilerinin seçiminde farklı sosyo-ekonomik niteliklere sahip okulların yöneticileri olmasına dikkat edilmiş ve bu sayede çeşitlilik sağlanmaya çalışılmıştır. Bununla birlikte çalışmada ölçüt örnekleme tekniği kullanılmıştır. Ölçüt örnekleme, araştırmanın problemiyle yakından ilgili olan kişilerin, olayların, nesnelerin ve durumların araştırmaya dahil edilerek örneklemin oluşturulmasıdır (Büyüköztürk vd., 2014). Bu çalışmada araştırmaya katılacak okulların belirlenmesinde ölçüt ikili eğitim yapan okullar olmasıdır. Bunun nedeni ise ikili eğitimden tam gün (normal) eğitime geçişte karşılaşılabilecek sorunları ve bu sorunların çözümüne yönelik önerileri ikili eğitim yapan okulların yöneticilerinin görüşleri doğrultusunda incelemektir.

Tablo 1. Araştırmaya Katılan Okul Yöneticilerinin Demografik Bilgileri

\begin{tabular}{|c|c|c|c|}
\hline Değişkenler & Alt kategoriler & $\mathbf{n}$ & Yüzde (\%) \\
\hline \multirow[t]{2}{*}{ Cinsiyet } & Kadın & 7 & 35 \\
\hline & Erkek & 13 & 65 \\
\hline \multirow[t]{2}{*}{ Görev } & Okul Müdürü & 9 & 45 \\
\hline & Müdür Yardımcısı & 11 & 55 \\
\hline \multirow[t]{5}{*}{ Yöneticilik Kıdemi } & $1-5$ y1l & 6 & 30 \\
\hline & 6-10 yil & 6 & 30 \\
\hline & $11-15$ yil & 1 & 5 \\
\hline & $16-20$ yıl & 2 & 10 \\
\hline & 21 yll ve üzeri & 5 & 25 \\
\hline \multirow[t]{3}{*}{ Ĕ̆itim Düzeyi } & Ön lisans & 2 & 10 \\
\hline & Lisans & 11 & 55 \\
\hline & Yüksek Lisans & 7 & 35 \\
\hline \multirow[t]{2}{*}{ Görev Yapılan Okul Türü } & İlkokul & 12 & 60 \\
\hline & Ortaokul & 8 & 40 \\
\hline Toplam & & 20 & 100 \\
\hline
\end{tabular}

Çalışma grubunda yer alan okul yöneticilerinin 7'si kadın ve 13'ü erkektir. Okul yöneticilerinin 9'u okul müdürü, 11'i müdür yardımcısıdır. Katılımcıların yöneticilik kıdemlerine göre dağılımı; 1-5 yıl kıdeme sahip olanların sayısı altı, 6-10 yıl kıdeme sahip olanların sayısı altı, 11-15 yıl kıdeme sahip olanların sayısı 1, 16-20 yıl kıdeme sahip olanların sayısı 2, 21 yıl ve üzeri kıdeme sahip olanların sayısı 5'tir. Katılımcıların eğitim düzeyine göre dağılımı; ön lisans mezunu 2, lisans mezunu 11 ve yüksek lisans mezunu 7'dir. Katılımcıların görev yaptıkları okul kademesine göre dağılımı; ilkokulda görev yapanların sayısı 12 ve ortaokulda görev yapanların sayısı 8 'dir. 


\section{Veri Toplama Aracı}

Araştırmada ikili eğitimden tam gün (normal) eğitime geçişte karşılaşılabilecek sorunları ve bu sorunların çözümüne yönelik önerileri ikili eğitim yapan okulların yöneticilerinin görüşleri doğrultusunda incelemek için yarı-yapılandırılmış görüşme formu kullanılmıştır. Görüşme formunun tercih edilme nedeni veri analizinin kolaylığı, görüşme yapılana kendini ifade etme kolaylığı ve derinlemesine bilgi sağlamasıdır (Büyüköztürk vd., 2014). Görüşme formu oluşturulmadan önce yurt içi ve yurt dışındaki literatür incelenmiş ve araştırmanın amacı kapsamında sorular hazırlanmıştır. Hazırlanan sorular eğitim yönetimi alanından 2 ve Türkçe alanından 1 olmak üzere toplam 3 uzmanın görüşüne sunulmuştur. Alan uzmanlarından alınan dönütler doğrultusunda bir soru çıkarılmıştır. Araştırmaya başlamadan önce araştırmanın çalışma grubundan olmayan 3 okul yöneticisiyle görüşülerek kapsam ve biçimsel yönden sorular incelenmiştir. Katılımcılara, ikili eğitimden tam gün (normal) eğitime geçişte karşılaşılabilecek sorunların ve bu sorunların çözümüne yönelik önerilerin ortaya çıkarılmasını amaçlayan aşağıdaki sorular sorulmuştur:

İkili eğitimden tam gün eğitime geçişte karşılaşabileceğiniz sorunlar nelerdir?

İkili eğitimden tam gün eğitime geçişte karşılaşabileceğiniz bu sorunlar sizce nasıl çözülebilir?

\section{Verilerin Toplanması}

Okul yöneticileriyle yapılan görüşmeler, 2 Ocak-15 Şubat 2017 tarihleri arasında araştırmacıl tarafından gerçekleştirilmiştir. Görüşmeler için önceden randevu alınmış ve çalışmanın amacı ile görüşme süreci hakkında yöneticilere bilgi verilmiştir. Görüşmeler yöneticilere görüşme formu verilerek gerçekleştirilmiştir. Araştırmada katılımcıların kendilerini rahat ve huzurlu hissedebileceği ve görüşlerini içtenlikle açıklayabilecekleri bir görüşme ortamı sağlanmasına özen gösterilmiş, uygun bir etkileşim ortamı oluşturulmuştur. Görüşmeler esnasında görüşme formunun yanı sıra veri kaybını en aza indirmek için katılımcıların da onayı alınarak ses kayıt cihazı kullanılmıştır. Her bir okul yöneticisiyle yapılan görüşmelerin süresi 30 ila 40 dakika sürmüş olup toplam 8 saatlik görüşme yapılmıştır. Görüşmelere başlanmadan önce katılımcılara gizlilik ve etik ilkeler doğrultusunda görüşmenin gerçekleşeceği, kişi ve kurum ismi belirtilmeyeceği, elde edilen verilerin sadece araştırmacı tarafından bilineceği açıklanarak ses kayıt cihazıyla kayıt yapılmasının onayı istenmiştir.

Tablo 2'de araştırmanın katılımcılarıyla yapılan görüşmeler detaylı olarak sunulmuştur.

Tablo 2. Okul Yöneticileriyle Yapılan Görüşmelere Ait Bilgiler

\begin{tabular}{|c|c|c|c|c|c|c|c|c|}
\hline Kod & Cinsiyet & Görev & $\begin{array}{l}\text { K1dem } \\
\text { (y1l) }\end{array}$ & $\begin{array}{l}\text { Eğitim } \\
\text { Düzeyi }\end{array}$ & $\begin{array}{l}\text { Görev } \\
\text { Yapılan Okul } \\
\text { Türü }\end{array}$ & $\begin{array}{l}\text { Görüşme } \\
\text { Tarihi }\end{array}$ & $\begin{array}{l}\text { Görüşme } \\
\text { süresi } \\
\text { (dakika) }\end{array}$ & $\begin{array}{l}\text { Görüşme } \\
\text { yer }\end{array}$ \\
\hline $\mathrm{Y} 1$ & Kadın & Müdür & 2 & Lisans & İlkokul & $03 / 01 / 2017$ & 32 & Müdür Odası \\
\hline $\mathrm{Y} 2$ & Erkek & $\begin{array}{l}\text { Müdür } \\
\text { Yardımcısı }\end{array}$ & 24 & Lisans & Ortaokul & $08 / 02 / 2017$ & 34 & $\begin{array}{l}\text { Müdür Yardımcisı } \\
\text { Odası }\end{array}$ \\
\hline Y3 & Erkek & Müdür & 7 & $\begin{array}{l}\text { Yüksek } \\
\text { Lisans }\end{array}$ & İlkokul & 08/02/2017 & 38 & Müdür Odası \\
\hline$Y 4$ & Kadın & Müdür & 6 & Lisans & İlkokul & 02/01/2017 & 36 & Müdür Odası \\
\hline Y5 & Erkek & $\begin{array}{l}\text { Müdür } \\
\text { Yardımcısı }\end{array}$ & 1 & Lisans & Ortaokul & 09/02/2017 & 33 & $\begin{array}{l}\text { Müdür Yardımcısı } \\
\text { Odası }\end{array}$ \\
\hline Y6 & Erkek & $\begin{array}{l}\text { Müdür } \\
\text { Yardımcısı }\end{array}$ & 22 & $\begin{array}{l}\text { Ön } \\
\text { lisans }\end{array}$ & İlkokul & $12 / 02 / 2017$ & 38 & $\begin{array}{l}\text { Müdür Yardımcısı } \\
\text { Odası }\end{array}$ \\
\hline
\end{tabular}




\begin{tabular}{|c|c|c|c|c|c|c|c|c|}
\hline Y7 & Erkek & Müdür & 8 & $\begin{array}{l}\text { Yüksek } \\
\text { Lisans }\end{array}$ & Ortaokul & $13 / 02 / 2017$ & 37 & Müdür Odası \\
\hline Y8 & Kadın & $\begin{array}{l}\text { Müdür } \\
\text { Yardımcısı }\end{array}$ & 3 & Lisans & İlkokul & 05/01/2017 & 36 & $\begin{array}{l}\text { Müdür Yardımcısı } \\
\text { Odası }\end{array}$ \\
\hline Y9 & Erkek & $\begin{array}{l}\text { Müdür } \\
\text { Yardımcısı }\end{array}$ & 12 & $\begin{array}{l}\text { Yüksek } \\
\text { Lisans }\end{array}$ & İlkokul & 05/01/2017 & 35 & $\begin{array}{l}\text { Müdür Yardımcısı } \\
\text { Odası }\end{array}$ \\
\hline Y10 & Kadın & $\begin{array}{l}\text { Müdür } \\
\text { Yardımcısı }\end{array}$ & 4 & Lisans & İlkokul & $13 / 02 / 2017$ & 34 & $\begin{array}{l}\text { Müdür Yardımcısı } \\
\text { Odası }\end{array}$ \\
\hline Y11 & Erkek & Müdür & 23 & $\begin{array}{l}\text { Yüksek } \\
\text { Lisans }\end{array}$ & Ortaokul & $03 / 01 / 2017$ & 35 & Müdür Odası \\
\hline Y12 & Kadın & $\begin{array}{l}\text { Müdür } \\
\text { Yardımcısı }\end{array}$ & 8 & Lisans & İlkokul & 05/01/2017 & 40 & $\begin{array}{l}\text { Müdür Yardımcısı } \\
\text { Odası }\end{array}$ \\
\hline Y13 & Erkek & Müdür & 16 & Lisans & Ortaokul & $18 / 01 / 2017$ & 39 & Müdür Odası \\
\hline Y14 & Kadın & Müdür & 5 & $\begin{array}{l}\text { Yüksek } \\
\text { Lisans }\end{array}$ & İlkokul & $09 / 01 / 2017$ & 30 & Müdür Odası \\
\hline Y15 & Erkek & Müdür & 9 & Lisans & İlkokul & $16 / 01 / 2017$ & 35 & Müdür Odası \\
\hline Y16 & Erkek & $\begin{array}{l}\text { Müdür } \\
\text { Yardımcısı }\end{array}$ & 24 & $\begin{array}{l}\text { Ön } \\
\text { lisans }\end{array}$ & İlkokul & $02 / 01 / 2017$ & 31 & $\begin{array}{l}\text { Müdür Yardımcisı } \\
\text { Odası }\end{array}$ \\
\hline Y17 & Erkek & $\begin{array}{l}\text { Müdür } \\
\text { Yardımcısı }\end{array}$ & 20 & Lisans & Ortaokul & 05/01/2017 & 34 & $\begin{array}{l}\text { Müdür Yardımcısı } \\
\text { Odası }\end{array}$ \\
\hline Y18 & Erkek & Müdür & 3 & $\begin{array}{l}\text { Yüksek } \\
\text { Lisans }\end{array}$ & İlkokul & 03/01/2017 & 38 & Müdür Odası \\
\hline Y19 & Kadın & $\begin{array}{l}\text { Müdür } \\
\text { Yardımcısı }\end{array}$ & 9 & Lisans & Ortaokul & $11 / 01 / 2017$ & 36 & $\begin{array}{l}\text { Müdür Yardımcisı } \\
\text { Odası }\end{array}$ \\
\hline Y20 & Erkek & $\begin{array}{l}\text { Müdür } \\
\text { Yardımcısı }\end{array}$ & 10 & $\begin{array}{l}\text { Yüksek } \\
\text { Lisans }\end{array}$ & Ortaokul & $15 / 02 / 2017$ & 39 & $\begin{array}{l}\text { Müdür Yardımcısı } \\
\text { Odası }\end{array}$ \\
\hline
\end{tabular}

\section{Verilerin Analizi}

Araştırmada elde edilen verilerin çözümlenmesinde içerik analizi tekniği kullanılmıştır. İçerik analizi, belirli kurallara dayalı kodlamalarla bir metnin bazı sözcüklerinin daha küçük içerik kategorileri ile özetlendiği sistematik, yinelenebilir bir teknik olarak tanımlanır (Büyüköztürk vd. 2014). Analize başlanmadan önce ses kayıtları yazılı hale getirilmiştir. Deşifre işleminin doğruluğunu kontrol etmek için ses kayıtlarından elde edilen veriler ve görüşme formundan elde edilen veriler karşılaştırılmıştır. Görüşmelerden 28 sayfa veri elde edilmiştir. Her bir soru için verilen cevaplardaki ortak noktalar dikkate alınarak kategori ve çeşitli kodlamalar yapilmıştır.

\section{Geçerlik-Güvenirlik Çalışmaları}

Çalışmanın güvenirlik ve geçerliğini sağlamak amacıyla ilk olarak yazılı hale getirilen görüşlerin katılımcılar tarafından kontrol edilmesi sağlanmıştır. Görüşmeler sonucu elde edilen veriler düzenlenip, tablolaştırıldıktan sonra katılımcılara gönderilerek paylaşılmıştır. Katılımcıların ifade etmek istedikleriyle araştırmacı tarafından oluşturulan tablolardaki ifadeler karşılaştırılarak teyit edilmiştir. Daha sonra araştırmanın verilerinden yola çıkarak oluşturulan kategoriler eğitim yönetimi alanından 2 uzmana (doktora mezunu) inceletilmiştir. 2 uzmandan alınan geri bildirimler ile araştırmacının eşleştirmeleri karşılaştırılmıştır. Karşılaştırma sonucunda 3 kod ilave edilmiş, sonrasında ise alt kategori ile kategorilerin kontrolü yapılmıştır. Kodlayıcı görüşleri Miles ve Huberman'ın (1994) P(Uzlaşma yüzdesi $)=\mathrm{Na}($ Görüş Birliği)/Na(Görüş Birliği $)+\mathrm{Nd}($ Görüş Ayrılığı)x100 güvenirlik formülü 
kullanılarak hesaplanmıştır. Bu formüle göre kodlayıcılar arasındaki uyum .92 olarak tespit edilmiştir.

\section{Bulgular}

Bu bölümde ikili eğitimden tam gün(normal) eğitime geçişte karşılaşılabilecek sorunlar ve bu sorunların çözümüne yönelik öneriler açığa çıkarılmaya çalışılmıştır. Bu doğrultuda okul yöneticilerinin görüşlerinden elde edilen bulgular ayrı tablolar halinde sunulmuştur.

\section{İkili Eğitimden Tam Gün (Normal) Eğitime Geçişte Karşılaşılabilecek Sorunlara İlişkin Bulgular}

Çalışma grubundaki okul yöneticilerine "İkili eğitimden tam gün eğitime geçişte karşılaşabileceğiniz sorunlar nelerdir?" sorusu yöneltilmiştir. Okul yöneticilerinden elde edilen yanıtlara göre oluşturulan görüşler Tablo 2' de yer almaktadır.

Tablo 3. İkili Eğitimden Tam Gün(Normal) Eğitime Geçişte Karşılaşılabilecek Sorunlara İlişkin Görüşler

\begin{tabular}{lll}
\hline S.N & Sorunlar & $\mathbf{n}$ \\
\hline 1 & Beslenme sorunu (öğle yemeği vb.) & 16 \\
\hline 2 & Fiziki mekân yetersizliği (sınıf sayısı vb.) & 13 \\
\hline 3 & Sinıfların kalabalıklaşması & 11 \\
\hline 4 & Kayıt alanı dışından gelen öğrenciler & 8 \\
\hline 5 & Öğretmenlerin norm fazlası olma durumu & 7 \\
\hline 6 & Yeni okul binası yapımıyla ilgili sorunlar & 5 \\
\hline 7 & Eğitim materyallerinin yetersizliği & 2 \\
\hline
\end{tabular}

Tablo 3'e göre okul yöneticilerinin ikili eğitimden tam gün eğitime geçişte karşılaşabilecekleri sorunlara ilişkin görüşleri; beslenme sorunu (öğle yemeği vb.) (n=16), fiziki mekân yetersizliği (sınıf sayısı vb.) ( $n=13)$, sınıfların kalabalıklaşması $(n=11)$, kayıt alanı dışından gelen öğrenciler $(n=8)$, öğretmenlerin norm fazlası olma durumu $(n=7)$, yeni okul binası yapımıla ilgili sorunlar $(n=5)$ ve eğitim materyali yetersizliği $(n=1)$ şeklindedir. Buna göre okulların tam gün eğitime geçiş sürecinde ikili eğitim yapan okul yöneticileri tarafından birden fazla sorun alanı olduğu ifade edilmiştir.

Okul yöneticilerinin görüşlerinden ikili eğitimden tam gün eğitime geçişte karşılaşabilecek en sık vurgulanan sorun öğle arası evine gidemeyecek olup okulda kalmak zorunda olan öğrencilerin beslenme sorunudur. Bu durum okulların çoğunda beslenme için ayrılmış bir alanın olmayışı ve öğrencilere yönelik okullarda yemek hizmeti sunulamamasından kaynaklanabilir. Katılımcılar çoğu tarafından okulların fiziki mekânlarının yetersizliği (sınıf sayısı vb.) ve sınıfların kalabalıklaşması tam gün eğitime geçişte karşılaşılabilecek diğer önemli sorunlar olarak ifade edilmiştir. İkili eğitim uygulamasında gün içerisinde iki kat daha fazla öğrenciye hizmet veren derslikler tam gün eğitimle birlikte bu öğrenci sayısının yarısına hizmet verebilecektir. Eğer yeteri kadar derslik yapılmazsa ikili eğitimdeki öğrenciler tam gün eğitime geçişle birlikte aynı sınıflarda eğitim görmek zorunda kalacak ve bu durumda sınıfların kalabalıklaşmasına neden olacaktır. Yöneticilerin görüşlerinden dikkat çekici olanlara aşağıda yer verilmiştir.

Y1: Çalışan anne babalar nedeniyle öğle yemeğine gitmeyecek çocukların okulda beslenme ve aradaki zamanda kontrol sıkıntısı yaşanacaktır. 
Y6: Tam gün eğitim yapılması için yeterli fiziki mekân olması gerekir. Belirlenen kayıt alanları korunarak dışarıdan gerçeği yansıtmayan fason kayıtların önüne geçilmesi.

Y10: Sını mevcutları artacaktır. Öğle arası evine gitmeyen öğrenciler için yemek sorunu yaşanabilir. Fiziki şartları yemekhane için uygun olmayan okullar sıkıntı yaşayabilir.

Y12: Sinıf mevcutları artacak. Öğretmenler norm fazlası duruma düşecek. Öğlen dinlenme saatinde okulda kalan öğrencilerin durumu.

Y16: Yeterli sayıda sınıfolmaması. Mevcut ikili ĕgitimde sabah ve öğleden sonra kullanılan sinıfların tam güne geçilmesiyle tek sefer kullanılması ve bunun sinıf mevcutlarmın çoğalmasina neden olması, sinıf birleşmesiyle öğretmenlerin norm fazlası olması, merkezi okullara kayıt alanı dışından kayıtların devam etmesi, yeni derslik yapımında gecikmelerin yaşanması, okul binası için merkezde uygun arsa bulma sıkıntısı, mevcut tam gün eğitim yapan okulların binalarının deprem dayanıklılık testinden geçememesi ve boşaltma kararı çıkması, bu okullarm da ikili eğitime geçmek zorunda kalması.

Y17: Öğlen arası eve gitmeyen öğrencilerin beslenme sorunu, simf mevcutlarım kalabalıklaşması, dersliklerin azlı̆̆ı, okulumuzun şehir merkezinde olması ve tam gün eğitime geçiş için ek bina, okul vb. yapılacak arsanın olmaması, binaların yapım sürecinin gecikmesi, kayıt alanlarına sahte adres değişikliği yapılarak gelinmesi ve buralarda bulunan okulların mevcudunun artması.

Y19: Tam gün eğitime geçiş için sınıf sayımız yeterli değil. Sınıflar birleştirilerek geçiş yapılırsa mevcutlar kalabalık olacak, öğretmenlerimiz fazlahı̆g çıkacaktır. Tam gün eğitime geçildiğinde çalışan ailelerin çocukları öğlen aralarında okulda kalma durumuyla karşılaşacaktır. Bu çocukların belenme sorunu ortaya çıkacaktır. Okulumuzda yemekhane olmadığı için öğlen okulda kalan çocuklar zor durumda kalacaktır. Okulumuzun kayıt alanlarına kayıt zamanında birçok aile adresini taşımakta ve okulumuza kayıt olmaktadır. Ailelerin bir kısmı gerçekte bölgemizde oturmasa bile göstermelik olarak adresini okulumuzun olduğu bölgeye taşımaktadır. Bu nedenle okul mevcudumuz sürekli artmakta, tam güne geçişimiz güçleşmektedir

\section{İkili Eğitimden Tam Gün Eğitime Geçişte Karşılaşılabilecek Sorunların Çözüm Önerilerine İlişkin Bulgular}

Çalışma grubundaki okul yöneticilerine "İkili eğitimden tam gün eğitime geçişte karşılaşabileceğiniz sorunlara yönelik çözüm önerileriniz nelerdir?" sorusu yöneltilmiştir. Okul yöneticilerinden elde edilen yanıtlara göre oluşturulan görüşler Tablo 3'de yer almaktadir.

Tablo 4. İkili Eğitimden Tam Gün Eğitime Geçişte Karşılaşılabilecek Sorunların Çözümüne İlişkin Görüşler

\begin{tabular}{llc}
\hline S.N & Öneriler & $\mathbf{n}$ \\
\hline 1 & $\begin{array}{l}\text { Hazırlıklar tamamladıktan sonra tam güne kademeli olarak } \\
\text { geçilmesi }\end{array}$ & 19 \\
\hline 2 & Öğlen yemek ihtiyacının karşılanması & 18 \\
\hline 3 & Okul binalarının yapım sürecinin hızlandırılması & 15 \\
\hline 4 & Okullar arası farklılıkların giderilmesi & 14 \\
\hline 5 & Kayıt alanı dışından öğrenci kaydının engellenmesi & 11 \\
\hline 6 & Norm fazlası olacak öğretmenlerin istihdam edilmesi & 10 \\
\hline
\end{tabular}


Tablo 4'e göre okul yöneticilerinin ikili eğitimden tam gün eğitime geçişte karşılaşabilecekleri sorunlara ilişkin çözüm önerileri; hazırlıklar tamamladıktan sonra tam güne kademeli olarak geçilmesi ( $n=19)$, öğlen yemek ihtiyacının karşılanması $(n=18)$, okul binalarının yapım sürecinin hızlandırılması $(n=15)$, okullar arası farklılıkların giderilmesi $(n=14)$, kayıt alanı dışından öğrenci kaydının engellenmesi $(n=11)$ ve norm fazlası olacak öğretmenlerin istihdam edilmesi $(\mathrm{n}=10)$ şeklindedir.

Tablo 4'te görüldüğü üzere katılımcların tamamına yakını eğitimden tam gün eğitime geçişin hazırlıklar tamamlandıktan sonra kademeli bir şekilde yapılması şeklinde görüş bildirmiştir. Bunun sebebi tam gün eğitim uygulamasına geçiş sürecinin çok boyutlu olmasından kaynaklandığı söylenebilir. Bu boyutlar incelendiğinde fiziki alt yapıyla ilgili çalışmaların öneminin ortaya çıktığı görülmektedir. Okulların fiziki alt yapısının tam gün eğitime hazır hale getirilmesi uzun süre ve ekonomik yönden ülke bütçesine maliyeti yüksek olan gerektiren konular olduğu bilinmektedir. Ülke olarak gerekli alt yapıyı sağlamadan ikili eğitimden tam güne geçilmesi sonrasında daha karmaşık problemlere yol açabileceği göz ardı edilmemelidir. Okul yöneticilerinin ikili eğitimden tam gün eğitime geçişte karşılaşabilecekleri sorunlara ilişkin çözüm önerilerine ilişkin dikkat çekici olanlara aşağıda yer verilmiştir.

Y2: Okullarda yemekhane oluşturularak isteyen öğrencilere hizmet alımı ile yemek verilebilir. Okulun fiziki imkânlarını arttırmak için yeni okullar yapılabilir.

Y3: Okul kayıt bölgesi daraltılarak öğrenci sayısı azaltılabilir. Öğlen arasında yemek problemi yemek şirketiyle anlaşllarak kantin bölgesinde yemek verilebilir.

Y4: Her okulun yemekhanesinin bulunması să̆lanmalı ve öğle yemeği verilmeli, okullar yeni binalarla desteklenmeli.

Y6: Kenar mahalleler ile merkezi okullar arasında bulunan eğitim yönünden farklılı̆̆ın giderilmesinin să̆lanması, taşradan merkeze kaçışların önlenmesi ile veya en aza indirilerek normal öğretime geçiş sağlanabilir.

Y8: Norm fazlası öğretmenler başka okullarda değerlendirilebilir.

Y16: Ilave derslik yapımının hılandırılması, adresini kayıt alanına taşıyanların denetiminin yapılması ve kayıt alanında oturmayanların kayıtlarının önlenmesi, öğlen arası okulda kalmak durumunda olan öğrenciler için yemekhane yapılması ve yemek verilmesi, boşaltma kararı çıkan okulların yerine hızlı bir şekilde yenilerinin yapılması, sinıf birleştirmeden yeni sinıflar yapılmadan okullar tam gün eğitime geçme konusunda zorlanmamalı, eksikler tamamlanınca geçiş sağlanmalı, kademeli geçiş olmalıdır.

Y17: Her okulun bir yemekhanesinin olması sağlanmalı, yeni sinıflar yapılarak sınıf mevcutlarının kalabalık olması önlenebilir. Kayıt alanında gerçekten oturmayanların kayıtlarının silinmesi, deprem testine alınan binaların yapımına öncelik verilmesi.

Y18: Çalışan ailelerin çocukları göz önünde bulundurularak öğlen arası okulda kalan öğrencilere yemek verilmesi gerekir. Sınıf birleştirme yerine ek sinıflar açılmall, kayıt alanlarında oturanlarm kontrolünün yapılması, okul binalarının yapımı hızlandırılmal, okulların hepsi bir tutulmamal, okulların eksikleri tamamlanmadan geçiş yapılmamalıdır. Gerekiyorsa kademeli geçiş yapılmalıdır

Y19: Okullara bulundukları bölgedeki öğrenci sayısı göz önünde bulundurularak ilave sınıflar yapılmalıdır. Öğlen okulda kalan çocuklara yemek verilmeli, okullara yemekhane 
yapılmalıdır. Okullara kayıt alanları dışından gelen öğrenciler kaydedilmemelidir. Okulların alt yapısı hazır olmadan geçiş başlatılmamalı, kademeli geçiş olmalıdır.

\section{Tartışma}

Araştırmada ikili eğitimden tam gün(normal) eğitime geçişte karşılaşılabilecek sorunlara ve bu sorunların çözümüne yönelik önerilere ilişkin ikili eğitim yapan okulların yöneticilerinin görüşleri ortaya konulmuştur. Araştırma sonucunda beslenme sorunu (öğle yemeği vb.), fiziki mekân yetersizliği (sınıf sayısı vb.), sınıfların kalabalıklaşması, kayıt alanı dışından gelen öğrenciler, öğretmenlerin norm fazlası olma durumu, yeni okul binası yapımıyla ilgili sorunlar ve eğitim materyali yetersizliği ikili eğitimden tam gün (normal) eğitime geçişte karşılaşılabilecek sorunlar olarak belirtilmiştir. Aktay, Işık ve Gençsoy, (2019) ilkokullarda eğitim-öğretim faaliyetlerinin tam gün ya da ikili öğretim biçiminde olmasının etkilerini ve özelliklerini ortaya koyduğu çalışmalarında tam gün öğretimde öğrencilerin tüm gün okulda kalmasıyla dikkatlerinin azalması, öğle yemeklerinin sorun olabilmesi gibi dezavantajları olduğu sonucuna ulaşmıştır. Camuzcu, (2007) da tam gün ve ikili eğitim uygulamalarını karşılaştırdığı araştırmasında öğrencilerin beslenme ihtiyaçlarına ve kalabalık sınıflara dikkati çekmektedir. Aynı şekilde Özan ve Öztürk' ün (2017) tam gün eğitime geçişte ortaya çıkabilecek problemleri incelediği araştırmada öğrencilerin öğle arası yemek ihtiyaçlarının karşılanması ve sınıf mevcutlarında meydana gelebilecek artış vurgulamıştır. Bununla birlikte Onarıcıoğlu'na (2018) göre normal öğretime göre ikili öğretim faaliyetlerine devam eden okullarda öğrencilerin yaşadıkları birçok problem mevcuttur. Vural \& Sadık'ın (2003) araştırmasındaki okullarda öğrencilerin beslenme ihtiyacını karşılamaya yönelik yemekhane ihtiyacı ile öğrenci sayısına uygun yeterli sayıda derslik olması gerektiği bulgusu araştırma bulgularını desteklemektedir. Gerek araştırmadan elde edilen bulgulardan gerekse literatürdeki ilgili diğer çalışmaların sonuçlarından tam gün eğitime geçişle birlikte okulları birtakım problemleri beklediği anlaşılmaktadır. Milli Eğitim Bakanlığı'nın bu problemlerin çözümüne yönelik somut adımlar atması ikili eğitimden tam gün eğitime geçişi sağlıklı bir şekilde gerçekleştirmek için faydalı olacaktır.

Araştırmanın katılımcılarının ikili eğitimden tam gün eğitim uygulamasına geçişte karşılaşılabilecek sorunlara ilişkin çözüm önerileri ise; hazırlıklar tamamladıktan sonra tam güne kademeli olarak geçilmesi, öğle yemeği ihtiyacının karşılanması, okul binalarının yapım sürecinin hızlandırılması, okullar arası farklılıkların giderilmesi, kayıt alanı dışından öğrenci kaydının engellenmesi ile norm fazlası olacak öğretmenlerin istihdam edilmesidir. Gedikoğlu, (2005) da yaptığı araştırmada Türk eğitim sisteminin benzer sorunları olduğunu bu sorunların ivedilikle çözülmesi gerektiğini vurgulamaktadır.

Milli Eğitim Bakanlığı politikalarının taşrada uygulayıcısı olan ve sorunlarla yüz yüze karşılaşan okul yöneticilerinin görüş ve önerileri problemlerin çözümü için atılacak adımların belirlenmesinde önemli bir veri kaynağı olarak değerlendirilebilir. Çünkü eğitimle ilgili alınan kararların uygulanması aşamasında sorunlarla bizzat karşılaşan okul yöneticilerinin görüşleri tam gün eğitime geçiş sürecinde de uygulamanın başarıya ulaşmasında yol gösterici olacaktır. İkili eğitimden tam güne geçiş sürecinde okulların fiziki ve diğer sorunları çözüldükten sonra kademeli bir şekilde geçilmeli, aceleci bir yaklaşımdan kaçınılmalıdır. Hazırlıksız bir şekilde tam gün eğitime geçişin sağlanması beklenen verimin de düşmesine neden olacaktır. 


\section{Öneriler}

Araştırma bulgularından yola çıkarak aşağıdaki önerilerde bulunulabilir:

Tam gün eğitime geçiş yapacak okullara karar verilmeden önce okulların mevcut fiziki alt yapı durumları gözden geçirilmelidir.

Öğrencilerin okulda beslenme ihtiyacını karşılamaya yönelik merkezi bütçeden gerekli pay ayrılmalı, okullarda uygun beslenme alanları oluşturulmalıdır.

İkili eğitimden tam gün eğitim geçiş sürecinde öğrenci sayısı, okul kayıt alanları, öğretmen sayılarına ait bilgiler bir veri tabanında toplanmalı, alınacak kararlar veriye dayalı olarak alınmalidir.

Her okul için tam gün eğitime geçiş planı hazırlanmalı, bu plan doğrultusunda gerekli hazırlıklar tamamlandıktan sonra geçiş kademeli olarak yapılmalıdır.

Yeni okulların yapım sürecinin hızlandırılması için sivil toplumun desteği sağlanmalı, bütçeden yeterli pay ayrılmalıdır.

Kalabalık sınıflara yol açabilecek durumların önlenmesi için gerekli idari yaptırımlar hayata geçirilmeli, okul kayıt alan dışından öğrenci kaydedilmemelidir.

Tam gün ve ikili eğitim uygulamalarının öğrenci öğrenmelerine etkisine yönelik karşılaştırmalı çalışmalar yapılabilir.

\section{Yazar Katkı Beyanı}

Araştırmanın tüm aşamaları (problemin belirlenmesi, uygulanacak araştırma yöntemine karar verilmesi, verilerin toplanması, analizi) yazar tarafından bilimsel araştırma yöntem ve tekniklerine uygun bir şekilde yürütülmüştür. Araştırmacı, çalışma yapılan alanda uzmandır ve süreçte yorumlar literatüre dayalı olarak kişisel yargılardan bağımsız olarak yapılmıştır.

\section{KAYNAKÇA}

Akbaşl1, S. \& Üredi, L. (2014). Views of teachers on the $4+4+4$ structure in the Turkish education system. Journal of Teacher Education and Educators, 3(1), 109-142.

Aktay, S., Işı1k, E. \& Gençsoy, E. (2019). Tam gün öğretim mi ikili öğretim mi? 3. Uluslararası Sınırsız Eğitim ve Araştırma Sempozyumu.

Büyüköztürk, Ş., Çakmak, E. K., Akgün, Ö, E., Karadeniz, Ş. \& Demirel, F. (2014). Bilimsel Araştırma Yöntemleri (18. Baskı). Ankara: Pegem Akademi

Camuzcu, S. (2007). Normal (tam gün) ve ikili öğretim (yarm gün) yapan ilköğretim okullarında birinci kademe öğrencilerinin genel başarılarının karşılaştırılması (Gaziantep Üniversitesi Örneği) (Yayımlanmamış Yüksek Lisans Tezi). Gaziantep Üniversitesi, Sosyal Bilimler Enstitüsü.Gaziantep.

Eğitim Reformu Girişimi (2014). Temel eğitimin kademelendirilmesi sürecine ilişkin politika önerileri.http://www.egitimreformugirisimi.org/wpcontent/uploads/2017/03/ERG_Teme 1-E\%C4\%9Fitimin-Kademelendirilmesi-S\%C3\%BCrecinin-\%C4\%B0zlenmesi.pdf adresinden 22 Mayıs 2019 tarihinde alındı. 
Ereş, F. (2005). Eğitimin sosyal faydaları: Türkiye AB karşılaştırması. Millî Eğitim Dergisi, 33(167). 33-42.

Gedikoğlu, T. (2005). Avrupa Birliği sürecinde Türk eğitim sistemi: Sorunlar ve çözüm önerileri. Mersin Üniversitesi Ĕ̆itim Fakültesi Dergisi, 1(1), 66-80.

Gullo, D. F. (2000). The long term educational effects of half-day vs full-day kindergarten. Early Child Development and Care, 160(1), 17-24.

Herry, Y., Maltais, C., \& Thompson, K. (2007). Effects of a full-day preschool program on 4year-old children. Early Childhood Research \& Practice, 9(2), 1-20.

Karakütük, K., \& Özdoğan Özbal, E. (2019). Eğitim yöneticilerinin yaşadıkları sorunlar ile sorun çözmede kullandıkları teknikler. Milli Ĕ̆itim Dergisi, 48(223), 33-60.

Kocaoluk, S. (1991). Ilköğretim Temel Mevzuat. İstanbul: Kocaoluk.

Lee, V. E., Burkam, D. T., Ready, D. D., Honigman, J., \& Meisels, S. J. (2006). Full-day versus half-day kindergarten: In which program do children learn more?. American Journal of Education, 112(2), 163-208.

Miles, M. B. \& Huberman, A. M. (1994). Qualitative Data Analysis: A Sourcebook. Beverly Hills: Sage.

Milli Eğitim Bakanlığı, (2014). Millî Ĕ̆itim Bakanlı̆̆ı okul öncesi eğitim ve ilköğretim kurumları yönetmeliği. Resmî Gazete Sayı: 29072 http://mevzuat.meb.gov.tr/dosyalar/1703.pdf adresinden 10 Mart 2020 tarihinde alındı.

Milli Eğitim Bakanlığı, +(2015). 2015-2019 Stratejik Plan. Milli Eğitim Bakanlı̆̆ı. Ankara. http://sgb.meb.gov.tr/meb_iys_dosyalar/2015_09/10052958_10.09.2015sp17.15imzasz.pd $\mathrm{f}$ adresinden 08 Şubat 2019 tarihinde alındı.

Milli Eğitim Bakanlığı, (2020). 2019 Yılı İdare Faaliyet Raporu. Milli Eğitim Bakanlı̆̆ı. Ankara. http://sgb.meb.gov.tr/meb_iys_dosyalar/2020_03/12144540_28191618_Milli_EYitim_Bak anlYYY_2019_YYlY_Ydare_Faaliyet_Raporu_28.02.2020.pdf adresinden 23 Haziran 2020 tarihinde alındı.

OECD, (2007). Reviews of National Policies for Education Basic Education in Turkey. http://www.oecd. org/edu/school/39642601.pdf adresinden 30 Mart 2020 tarihinde alındi.

Onarıcıoğlu, A. (2018). Normal öğretime geçişini tamamlayan okullardaki Türkçe eğitimi başarısı. Okuma Yazma Ĕ̆itimi Araştırmaları, 6 (2) , 96-110.

Özan, M.B. \& Öztürk, E. (2017, Mayıs 11-13). Normal (tam gün) eğitime geçişe ilişkin yönetici görüşleri.12. Uluslar Arası Eğitim Yönetimi Kongresi, Ankara, Türkiye.

Pınar, A. \& Sarıbaş, M. (2010). Okur yazar nüfus oranı Türkiye ortalamasının altında olan bir ilçe: Altınyayla (Sivas). Selçuk Üniversitesi Sosyal Bilimler Enstitüsü Dergisi 24, 291-309.

TRT, (2017). Orta vadeli programdaki eğitim konuları. Türkiye Radyo Televizyon Kurumu http://www.trthaber.com/m/?news=orta-vadeli-programdaki-egitim konulari\&news_id=275570\&category_id=12 adresinden 03 Mart 2020 tarihinde alınd1.

Vural, R.A. Sadık, F. (2003). İlköğretim okul binalarının fiziksel açıdan değerlendirilmesi. Ĕ̈itim ve Bilim, 28(130), 16-23. 
Ünal T. (2001). Milli Ĕgitim Davamız. Ankara: Berikan.

Yıldırım, A. \& Şimşek, H. (2016). Sosyal Bilimlerde Nitel Araştırma Yöntemleri. Ankara: Seçkin.

Yurdabakan, İ. \& Tektaş, M. (2013). Taşımalı ilköğretim öğrencilerinin taşımalı eğitime ilişkin görüşleri. Sosyal Bilimler Enstitüsü Dergisi, 15(3), 511-528.

Yücel, C., Boyacı, A., Demirhan, G., \& Karataş, E. (2013). Milli eğitim örgüt sisteminde ‘kayıt alanı' (hinterland) uygulamasının yönetsel işlevselliğinin değerlendirilmesi ve ekonomik, sosyal ve kültürel sermaye açllarından doğurduğu problemlerin incelenmesi. Kuram ve Uygulamada Ĕ̆itim Yönetimi, 19(1), 135-151. 